\title{
GRUNDTVIG-SELSKABETS \\ TILBLIVELSE OG VIRKSOMHED \\ I DETS FØRSTE TIÅR
}

\author{
Af Henning Høirup.
}

\section{Grundtvig-Selskabets stiftelse.}

Det kan næppe afgøres, hvem der først fostrede tanken om at stifte Grundtvig-Selskabet. Ønsket om et fælles forum for studiet af Grundtvig og et nært videnskabeligt samarbejde om de mange opgaver, der lå uløst, levede sikkert hos de fleste af de forskere, der midt i 40'rne hver for sig var i gang med kildeundersøgelser. Ved samtaler på Det kongelige Bibliotek og under de »grundtvigske arbejdskonventer«, som holdtes på Kerteminde Højskole i 1946 og 1947, blev sagen bragt på bane. Ganske tydeligt erindrer jeg, at det var lederen af de sidstnævnte møder, biskop Hans Øllgaard, der under en sådan drøftelse foreslog navnet »Grundtvig-Studier«, som nu for tiende gang bæres af Selskabets årbog.

Oprettelsen blev besluttet under et samvær af tre litteraturforskere og tre teologer, som under deres arbejde havde indset, hvor nødvendig og gavnlig en gensidig orientering vilde være. GrundtvigSelskabets protokol, ført af Helge Toldberg, meddeler:

Efter indbydelse af biskop, dr. C. I. Scharling og stiftsprovst, dr. Villiam Gronbæk mødtes i dagene 6.-8. september 1947 sognepræst Henning Høirup, Balslev-Ejby, cand. mag. Steen Johansen, København, lektor William Michelsen, Uppsala, og cand. mag. Helge Toldberg, København, i Ribe til drøftelse af en række problemer af betydning for Grundtvig-forskningen efter nedenstående arbejdsplan, der nøje gennemførtes. Foruden de fremmødte var mag. art. Magnus Stevns indbudt, men forhindret $i$ at komme til stede.

Arbejdsmøderne, hvoraf de 3 første og det sidste afholdtes i stiftsprovstegården, de øvrige i bispegården, var følgende:

1. Lektor Michelsen: Tilblivelsen af Grundtvigs historiesyn.

2. Biskop Scharling: Grundtvig og Romantikken belyst ved Grundtvigs Forhold til Schelling.

3. cand. mag. Toldberg: Grundtvig i 1830'rne.

4. cand. mag. Steen Johansen: Forelæggelse af Grundtvig-bibliografien.

5. Pastor Høirup: Grundtvig og Locke.

6. Stiftsprovst Grønbæk: Nogle psykologiske teorier hos Grundtvig. 
7. cand. mag. Toldberg: Grundtvigs Englandsrejser. - Nugent Wade i Helsingør. (Ved dette sidste møde var ud over deltagerne i mødet en kreds af indbudte til stede).

På mødet redegjorde alle deltagere for anlægget og omfanget af deres arbejde, og under forhandlingerne, der stod på fra morgen til sen aften, var der rig lejlighed til at drøfte vor forsknings sigte og midler. Det viste sig også muligt at foretage en praktisk »deling af riget« mellem de enkelte forskere, så deres studier koordineredes, og alle var enige om, at senere møder vilde være meget ønskelige.

Søndag aften den 7. september var vi samlede i bispegården. Da aftenens emne var behandlet, fortsatte vi med at debattere den mulighed, biskop Øllgaard og jeg i den allerede nævnte samtale havde drøftet: at stifte et selskab med det formål at fremme Grundtvigforskningen og publicere en del af dens nyvundne resultater i et årsskrift. Klokken slog tolv i bispekontoret, hvor litografier af Mynster og Martensen og Tuxens maleri af Henrik Scharling, biskoppens fader, også en af Grundtvigs erklærede modstandere, stirrede ned fra væggene. Kort efter besluttede vi at søge dannet et frit og åbent samfund for arbejdet med Grundtvigs mangesidede indsats.

Næste dag, på Grundtvigs fødselsdag den 8. september, fandt det stiftende møde sted i Ribe Bispegård kl. 17. Man vedtog at søge kredsen af stiftende medlemmer udvidet med fhv. overbibliotekar Vilh. Grundtvig, Århus, biskop Hans Øllgaard, Odense, professorerne dr. jur. Poul Andersen og dr. theol. Hal Koch, København, dr. theol. Regin Prenter, Århus, og Kemp Malone, D. Ph., The Johns Hopkins University, Baltimore, fhv. seminarieforstander Georg Christensen og lektor, dr. phil. Gustav Albeck, Århus, samt mag. art. Magnus Stevns. Der blev opsat udkast til love og vedtaget retningslinier for Selskabets fremtræden for offentligheden. Det overlodes Toldberg at fungere som sekretær og mig at planlægge første årgang af Grundtvig-Studier.

Ribe-mødet, som står varigt indskrevet i deltagernes erindring, var ikke sammenkaldt med stiftelsen af Grundtvig-Selskabet for øje. Vedtagelsen groede frem under indtrykket af den værdi, som det begyndende arbejdsfællesskab indebar. Jeg skal ikke her, hvor skildringen gælder Selskabets tilblivelse, gøre nærmere rede for de syv foran nævnte foredrag, som ikke blev refereret; men samtlige disse indlæg har siden sat sig litterære spor, der gør det muligt at danne sig et fyldigt billede af vore drøftelsers gang og udbytte. Længst fremme i sit arbejde var biskop Scharling, hvis bog: Grundtvig og Romantiken, belyst ved Grundtvigs Forhold til Schelling udkom samme efterår en af mødedagene bragte posten biskoppen korrektur på omslaget. 
Scharling havde langt tidligere skrevet en afhandling »Naturfølelsen hos Grundtvig« (1927); at han nu - trods de mange krævende opgaver i sin gerning og under daglig kamp med sygdom - havde gennemført dette sit hovedværk, var en indsats, som gjorde det dobbelt naturligt, at han med sin forhandlingsåbne og midtsamlende personlighed blev Grundtvig-Selskabets første formand. Steen Johansen forelagde ved mødet et fortryk af indledningen og de første 12 sider af sin Bibliografi over N.F.S. Grundtvigs Skrifter, hvis første bind udkom i 1948 og som afsluttedes med fjerde bind 1954. Dette værk, med sine næsten 1500 sider, er nu det uundværlige arbejdsmiddel for ethvert studium af Grundtvigs forfatterskab.

De nævnte to værker, som var under udgivelse, kunde ikke komme med i det nystiftede Selskabs publikationer, hvor ellers alle de øvrige deltageres væsentlige arbejder i de følgende år fremkom. Toldbergs afhandling om »Nugent Wade i Helsingør. En engelsk præsts møde med Grundtvig og Mynster« blev trykt i Grundtvig-Studier (1948) og hans disputats: Grundtvigs symbolverden (1950) fremkom som bind II af »Skrifter udgivet af Grundtvig-Selskabet«. Bind I af denne serie var min doktorafhandling Grundtvigs Syn paa Tro og Erkendelse. Modsigelsens Grundsætning som teologisk Aksiom hos Grundtvig (1949). Siden udkom, som bind IV, Gronbæks afhandling Psykologiske tanker og teorier hos Grundtvig (1951) og ligeledes William Michelsens doktordisputats: Tilblivelsen af Grundtvigs historiesyn (bd. VI, 1954), hvortil slutter sig arbejdet Den sælsomme forvandling i N. F. S. Grundtvigs liv (bd. IX, 1956).

Naturligvis var det kun enkelte afsnit af disse arbejder eller deres hovedlinier, som fremførtes på mødet. Men for alle de fem sidstnævnte betød tankeudvekslingerne med arbejdsfæller og kendskabet til deres studieresultater en inspiration til selv at fortsætte og en tilskyndelse til at gennemføre en hensigtsmæssig indbyrdes arbejdsfordeling. At vi ønskede at videreføre og udvikle den vundne kontakt, var ganske ligetil. Men vilde det også lykkes at interessere en tilstrækkelig stor kreds for vor plan om Grundtvig-Selskabet?

Der indløb tilslutning fra den udvidede stifterkreds, som var foreslået på Ribe-mødet, og yderligere indtrådte pastor Th. Balslev, Vartov, blandt de stiftende. Disse samledes (med undtagelse af Prenter, Kemp Malone, V. Grundtvig og Michelsen, som var forhindrede) den 13. januar 1948 til det konstituerende møde, der fandt sted i Vartovs konfirmandstue kl. 16 under forsæde af biskop Scharling. Der blev nedsat et forretningsudvalg med denne som formand, seminarieforstander Georg Christensen som næstformand, Toldberg som sekretær og midlertidig kasserer (denne post overtoges kort efter af stud. theol. 
Morten Øllgaard, der efter mødet blev anmodet om at indtræde i styrelsen) og Høirup som redaktør. Fra mødet udsendtes følgende Ritzau-meddelelse:

På et møde i Vartov i dag er der stiftet et Grundtvig-Selskab, hvis formål er at fremme studiet af N. F. S. Grundtvig, hans virke og hans stilling $\mathrm{i}$ åndslivet $\mathrm{i}$ og udenfor Danmark. Selskabet agter $\mathrm{i}$ lighed med Holberg- og H. C. Andersen-Selskaberne at udsende en årbog, 》Grundtvig-Studier«. Alle interesserede kan blive medlemmer. (Derefter listen over de femten stiftere $\mathrm{i}$ alfabetisk orden og forretningsudvalget).

For at skabe en kassebeholdning erlagde de tilstedeværende straks et »stifterkontingent«. Det vedtoges at søge gennemført, at årsskriftet udkom på Grundtvigs fødselsdag. Årsmødet berammedes til fredag i efterårsferien. Forskningen blev ikke forsømt på mødet, som fortsattes om aftenen, selvom det blev sent, inden dr. phil. Gustav Albeck fik ordet for at holde sit foredrag Omkring Grundtvigs Digtsamlinger, et forarbejde til bogen af samme navn, som udkom 1955 med undertitel: Studier i Grundtvigs lyriske Forfatterskab 1808-1816.

I januar 1948 indtrådte efter opfordring foruden Morten Øllgaard redaktør mag. art. Emil Frederiksen, København, sognepræst Kaj Thaning, Asperup, og højskolelærer, dr. phil. Holger Kjær, Askov, i styrelsen. Næstformandens forhandling med Gyldendals Forlag i samme måned resulterede $\mathrm{i}$, at Forlaget påtog sig at udgive et årsskrift på 6 ark, trykt i 1000 eksemplarer. Direktør Ingeborg Andersen viste Selskabet stor velvilje, og forlaget ydede udstrakt hjælp, bl. a. ved fremstillingen af en henvendelse til offentligheden og Selskabets første brochure. Dermed indledtes et samarbejde, som siden er vedblevet, idet alle Selskabets 20 publikationer er udkommet i forlag eller kommission hos Gyldendal.

\section{Selskabets virksomhed $i$ biskop Scharlings formandstid.}

I Selskabets første leveår virkede styrelsen naturligvis for tilgang af medlemmer, dels personligt, dels ved bladartikler (af Th. Balslev, V. Grønbæk, Høirup og Toldberg - se Grundtvig-Studier 1951, s. 130). Kort efter et radioforedrag ${ }^{12} / 8$ af Toldberg om moderne Grundtvigforskning kunde formanden meddele styrelsen, at medlemstallet var kommet op på godt 250 - hvilket syntes at bekræfte Gyldendals nøgterne profeti om, at netop dette antal var, hvad »et lærd selskab« i Danmark sædvanlig kunde påregne!

Allerede den 14. april 1948 havde forretningsudvalget ved en pressemodtagelse i Vartov gjort opmærksom på Selskabets eksistens. 
Samtidig forelå der fra dets første udenlandske medlem (bortset fra medstifteren, professor Kemp Malone) dr. Noëlle Davies, Wales, som i 1931 havde udgivet sit betydelige skrift om Grundtvig: Education for Life, et tilbud om vederlagsfrit at udarbejde engelske resuméer af artiklerne i »Grundtvig-Studier«, og det blev således muligt fra begyndelsen at tage dette rimelige og påkrævede hensyn til det stadigt voksende antal af udenlandske medlemmer.

Et vigtigt, praktisk spørgsmål: om bedre vilkår for benyttelsen af Grundtvig-arkivet på Det kgl. Bibliotek, blev rejst af det ældste styrelsesmedlem, overbibliotekar Vilh. Grundtvig, der personlig henvendte sig til rigsbibliotekar Svend Dahl. Trods al imødekommenhed kunde et særlokale, med adgang til at skrive på maskine, ikke tilvejebringes på selve biblioteket, der led af pladsmangel; men udenbys boende forskere fik adgang til hjemlån af arkivalierne. Savnet af egnet arbejdsrum blev allerede næste år afhjulpet. Indretningen af Grundtvig-Biblioteket $i$ Vartov var i sommeren 1949 så langt fremme, at Vartovs ledelse - i forståelse af vort behov - kunde stille dette bibliotek til fri benyttelse for Selskabets studerende medlemmer. Som gave fra »Selskabet for de skiønne og nyttige Videnskabers Forfremmelse« (hvis formand var biskop Scharling) modtog Grundtvig-Selskabet en stor brandsikker box, som opstilledes i Grundtvig-Bibliotekets læsesal. Rigsbibliotekaren gav herefter (i skrivelse af $18 / 11$ 1948) tilladelse til, at Grundtvig-arkivet benyttedes i Vartov i forskningsøjemed. Her har en stor del af registreringen af Grundtvig-arkivet fundet sted, ligesom Grundtvigstudiet i det hele gennem årene har haft et påskønnet arbejdssted i de smukke lokaler, som rummer en righoldig, stedse voksende samling Grundtvig-litteratur.

I sommeren 1948 begyndte også en lang række forhandlinger om tilrettelæggelsen af en plan for en videnskabelig og såvidt mulig fuldstændig udgave af Grundtvigs trykte og utrykte skrifter. Efter opfordring fra professor $\mathrm{Hal} \mathrm{Koch}$ havde Helge Toldberg og William Michelsen tidligere (i 1946) ud fra hver sine synspunkter udarbejdet en udgaveplan. Dels i forretningsudvalgsmøder, dels under flere møder af de eventuelle »udgiveremner« (Albeck, Høirup, Steen Johansen, Michelsen, Stevns og Toldberg) drøftedes principperne for en sådan udgivelse. Udgavens uhyre omfang og dens vanskelighed ikke mindst på grund af det utrykte materiales mængde og delvis kaotiske tilstand - bevirkede, at man straks begrænsede planen til i første omgang kun at omfatte Grundtvigs forfatterskab til udgangen af 1815. Under disse forhandlinger rejstes to forslag, som Selskabet siden har arbejdet for, dels om mikrofotografering af de ældste og vigtigste dele af arkivet, hvorved man kunde forebygge arkivaliernes 
ødelæggelse ved slid eller brand, dels om udarbejdelsen af en udførlig registrant over Grundtvigs manuskripter.

Flere af disse drøftelser fandt sted i sekretærens hjem, hvor også professor Kemp Malone under besøg i Danmark ( ${ }^{24} / 8$ 1948) holdt sit første foredrag på dansk om Grundtvigs internationale betydning ${ }^{1}$ ).

Til den berammede dato, den 8. september 1948, udsendtes Grundtvig-Studier for første gang, indledt af en udgivelse af Grundtvigs hidtil utrykte håndskrift Pilegrimen og Pilegrimen fra Zante, udkast til en fortælling med selvbiografisk islæt, vistnok tillige tænkt som et »forsvarsskrift« for kristendommen. Om den linie, der er forsøgt holdt i »Grundtvig-Studier《, som jeg redigerede til og med 1952, mener jeg at kunne henvise til, hvad jeg sagde på Selskabets første årsmøde: årbogen »skal først og fremmest være et focus for videnskabeligdokumentarisk Grundtvig-forskning«. - Hvad »Grundtvig-Studier« (nærværende årgang medregnet) har bragt i sine ti første år, fremgår af den samlede indholdsoversigt med tilhørende registre her $\mathrm{i}$ bogen s. $90-132$.

Ved Selskabets første årsmøde den 22. oktober 1948 i Vartov var medlemstallet 333, og formanden udtalte $i$ sin beretning ved eftermiddagsmødet, at $\gg 5-600$ medlemmer måtte være målet《. Som det indledende bind i den planlagte serie Skrifter udgivet af GrundtvigSelskabet bebudedes den første danske Grundtvig-disputats: Grundtvigs Syn paa Tro og Erkendelse, der vilde blive trykt i 1.275 ekspl. og blive tilbudt medlemmerne til favørpris. (Skriftet udkom ${ }^{27 / 1} 1949$ ). Efter forhandling vedtoges Selskabets love (trykt i Grundtvig-Studier 1950, s. 110). Forstander Ernst J. Borup, Vartov, indtrådte i styrelsen (og blev få måneder senere næstformand, da Georg Christensen ønskede at træde tilbage). I eftermiddagens foredrag fremlagde universitetslektor William Michelsen en undersøgelse af Grundtvigs »Verdens-Krønike« 1817, og om aftenen, hvor Studenterkredsen var indbudt, talte mag. art. Magnus Stevns om »Kingosalmen og Grundtvig«. Stevns havde umiddelbart før mødet ligget alvorligt syg, og at han kom til at tale - og tale som han gjorde - var i virkeligheden et under. Dette foredrag, hvori forskerens tekstundersøgelser og medviderens indlevelse forenedes så smukt, glemmes ikke. Vi bad straks om manuskriptet til »Grundtvig-Studier«, og skønt han måtte tilrettelægge det til udgivelse under kamp med den tiltagende sygdom og nødigt vilde slippe det, lykkedes det tilsidst. Da det fremkom, i anden årgang (1949), var Magnus Stevns død (30. marts 1949).

1) Om Kemp Malones arbejde med Grundtvig se: Grundtvig belyst af en moderne anglist, af Helge Toldberg, Grundtvig-Studier 1948, s. $98 \mathrm{ff}$. 
I Selskabets andet virkeår arbejdede styrelsen med den allerede nævnte plan om »den store udgave«. Et økonomiudvalg nedsattes ${ }^{23} / 10$ 1948, bestående af biskopperne Scharling og Øllgaard, professor Hal Koch, forstander Arnfred og ungdomsskolekonsulent Johs. Novrup. Den førstnævnte og professor Ernst Frandsen blev udpeget til tilsynsråd. En række orienterende forhandlinger blev i dette og det følgende år ført, bl. a. med Gyldendal, Carlsbergfondet, Det danske Sprog- og Litteraturselskab og med undervisningsminister, dr. phil. Hartvig Frisch, der viste stor forståelse for Selskabets arbejde.

Det stod allerede ved overvejelsernes begyndelse klart, at det første skridt på den lange vej frem måtte blive en indgående, systematisk undersøgelse af det utrykte materiale. I november modtog Selskabet $2000 \mathrm{kr}$. af Overretssagfører L. Zeuthens Mindelegat »til Registrering af Grundtvigs efterladte Papirer i Det kgl. Bibliotek, hvorved disse gøres tilgængelige for almindelig Forskning«. Ved et ekstraordinært styrelsesmøde 18/2 1949 kunde således registreringen iværksættes og det overdroges Høirup at arbejde med teologiske håndskrifter, Thaning med prædikener, Albeck med materialet vedrørende Poetiske Skrifter og Toldberg med fascikler af mytologisk og filologisk indhold. Dette arbejde skred godt fremad, selvom det medførte mange og lange drøftelser for at finde frem til ensartede registreringsprincipper. Fornyede bevillinger i 1950 og 1952 gjorde det muligt at gennemarbejde yderligere partier af arkivet.

På forslag af sekretæren begyndte Selskabet i 1949 at afholde lokale møder. Ved de to første, i Vartov $5 / 4$ og $7 / 51949$, talte Toldberg om »Grundtvig som digter« og Høirup om »Grundtvigs syn på forsagelsen i dåbspagten«. Senere på året holdt mag. art. Emil Frederiksen foredrag om $\gg$ Nyaars-Morgen, kunstnerisk betragtet«.

Arsmodet 1949 holdtes i Århus den 21. oktober. Ved åbningsmødet i Katedralskolens solennitetssal aflagde formanden beretning, og til styrelsen nyvalgtes (efter Stevns' død) valgmenighedspræst Uffe Hansen og til tilsynsrådet professor, dr. phil. P. Skautrup. Derefter talte Albeck om Grundtvigs forhold til katedralskolen. Hovedforedraget holdtes af formanden: »Det eskatologiske hos Grundtvig« (trykt i Grundtvig-Studier 1950 med overtitel: Kristi Genkomst og Kødets Opstandelse). Ved aftenmødet i Universitetets store auditorium var der foredrag af pastor Th. Balslev: »Om Christenhedens Syvstjerne«. Balslevs senere udgave af dette digt (1955) var blandt de skrifter, som Selskabet skaffede sine medlemmer til favørpris.

Det efterfølgende styrelsesmøde vedtog på redaktørens forslag at udgive Magnus Stevns' afhandlinger om Grundtvig. Under titlen Fra Grundtvigs Salmeværksted fremkom udgaven (ved Høirup og Steen 
Johansen) i 1950 som bind III af Grundtvig-Selskabets Skrifter (trykt i 1350 eksemplarer, det største oplag, vi hidtil har vovet). Både denne bog og Grundtvig-Studier 1950 udkom på ny basis - i kommission - hos Gyldendal, en ordning som siden har været benyttet. Årbogen og de fleste af Selskabets andre publikationer er siden da trykt af Aarhuus Stiftsbogtrykkerie.

Arbejdet med Grundtvig-arkivet var nu godt i gang. Mikrofotograferingsudvalget (nedsat ${ }^{23} / 101948$ med 5 medlemmer, men ${ }^{18} / 21949$ indskrænket til 2: Toldberg og Albeck) havde henvendt sig til rigsbibliotekar Sv. Dahl, der atter viste stor forståelse og under ${ }^{14} / 21949$ gav tilsagn om at ville lade det materiale, som udvalget foreslog, fotografere efterhånden, idet udgifterne afholdtes over det ordinære budget (herfor var også minister Hartvig Frisch gået ind). I de følgende år er en betydelig række vigtige håndskrifter derefter blevet mikrofotograferet. Ved registreringen indvandtes erfaringer, som straks kunde komme forskningen til gode, idet registranten afleveredes i maskinskrevet stand med flere genparter. I første række tjente disse til orientering for medarbejderkredsen, men i flere tilfælde har allerede denne foreløbige registrant kunnet udnyttes i Grundtvig-litteraturen.

I løbet af 1950 lysnede det for Selskabets budget. Carlsen-Langes Legatstiftelse ydede tilskud til »Grundtvig-Studier« og Rask-ØrstedFondet ligeledes, til de engelske resuméer (begge de næunte fonds har flere gange siden ydet Selskabet værdifuld støtte). - De lokale møder fortsattes i København $1 / 3$ og begyndtes i Århus $8 / 3$, begge steder med professor, dr. theol. P. G. Lindhardt som taler: »Den grundtvigske præstefrihedstanke. Ideal og virkelighed«. Skønt tilhørerkredsen oftest er lille, har disse møder stor betydning for Selskabets arbejde, og foredragene har ofte affødt afhandlinger til vore udgivelser $^{2}$ ).

Ved årsmødet ${ }^{20} / 10$ 1950, atter i Vartov, indvalgtes professor Skautrup i stedet for Vilh. Grundtvig, der var død ${ }^{22} / 4$, og valgmenighedspræst Uffe Hansen indtrådte i de registrerendes rækker. Om efter-

2) Da Grundtvig-Selskabets årsberetning hidtil aldrig er blevet trykt, vil det være rimeligt her at nævne de foredrag ved lokale moder, som denne fremstilling ikke omtaler $i$ anden forbindelse.

Vartov $27 / 4$ 1950: Cand. mag. Erik Moller om »Grundtvig og Treårskrigen « (fremkom samme år i Grundtvig-Studier under titlen: Grundtvig 1848 - 50. - På samme forfatters bog: 》Grundtvig som Samtidshistoriker«, 1950, opnåede Selskabet favørpris).

Vartov 2/3 1951: Høirup om »Grundtvig i 1867 « (trykt i GrundtvigStudier samme år).

Vartov ${ }^{26 / 3}$ 1952: Stud. mag. Niels Kofoed om 》Grundtvig 1805-10«, 
middagen talte Villiam Grønbæk om »Psykologiske tanker hos Grundtvig«. Aftenmødet, hvortil Studenterkredsen var indbudt (en siden stadig fulgt tradition), fik sit særlige præg ved at professor, dr. phil. Arthur Arnholtz' foredrag »Melodier til Grundtvigs salmer« ledsagedes af en smuk fremførelse af både romantiske og nye melodier af stud. mag. Ilse Arnholtz, talerens datter. Foredraget, som gentoges ved et lokalt møde på Århus Universitet ${ }^{12} / 31951$ (i forening med Jysk Selskab for nordisk Filologi), blev trykt i Grundtvig-Studier 1952.

I Selskabets årbog for 1951 bragtes en bibliografisk oversigt, ved cand. mag. Steen Johansen, over Grundtvig-Litteratur 1945-49. Ønsket om en sådan løbende oversigt over tilvæksten i Grundtviglitteraturen var fremsat fra amerikansk side. Denne bibliografi har siden været et fast og skattet inventar $\mathrm{i}$ årbogen.

Ved styrelsesmødet ${ }^{21} / 101950$ havde jeg udkastet den »flyvetanke«, at vi i 1951 - hundredåret for Grundtvigs beøg i Norge efter indbydelse af de norske studenter - skulde søge afholdt et stævne på Lysebu. Professor Ejnar Thomsen, der havde sæde i »Fondet for

et forarbejde til bogen »Grundtvig som selvbiograf«, der udkom som bind VIII i Selskabets 》Skrifter《 (1954).

Vartov 3/4 1952: Biskop, dr. theol. N. M. Plum om »Grundtvig og Københavns Præstekonvent«.

Århus 14/10 1952 (fællesmøde med Teologisk Forening i Århus): Stud. theol. Niels Gårdhus Sorensen om »Grundtvig og Irenæus med særligt henblik på opfattelsen af mennesket«.

Vartov 10/2 1953: Stud. theol. K. E. Bugge om 》Grundtvigs Landemodetaler« (se Grundtvig-Studier 1954).

Vartov 12/5 1953: Th. Balslev om 》Christenhedens Syvstjerne«.

Københavns Universitet ${ }^{24} / 21954$ (fallesmøde med Kierkegaard-Selskabet) : Høirup »Om begrebet menighed hos Grundtvig og Søren Kierkegaard« (jfr. 》Grundtvig and Kierkegaard, their Views of the Church« $i$ Grundtvig-Studier 1956).

Vartov 22/3 1954: Steen Johansen: „Ved Grundtvig-bibliografiens afslutning« (trykt samme år i Grundtvig-Studier under titel: Om Grundtvigbibliografiens tilblivelse).

Vartov 5/4 1954: Sognepræst Kaj Thaning om »Grundtvigs gennembrud som salmedigter«.

Vartov 21/4 1954: Dr. Toldberg om »Grundtvig og rimkrøniken« (jfr. Grundtvig-Studier 1954).

Vartov 2/12 1954: Professor dr. phil. Steffen Steffensen: „Grundtvig og romantikken «.

Vartov $\% / 3$ 1955: Pastor Valdemar Nielsen om »Salmedigteren Grundtvig og Norge«.

Vartov 13/4 1955: Cand. theol. A. Pontoppidan Thyssen om »Grundtvig som partistifter«.

Vartov ${ }^{11} / 5$ 1955: Dr. Toldberg om »Baggrunden for Nyaars-Morgen«. 
Dansk-Norsk Samarbejde«s professorudvalg, bidrog stærkt til at fremme Selskabets andragende, som til biskop Scharlings store glæde blev imødekommet; men umiddelbart før stævnet døde biskoppen, den 13. august 1951, efter kort tids sygdom.

I biskop Scharlings formandstid førtes Grundtvig-Selskabet ud af drømmestadiet og ind i en støt virksomhed. Under hans ledelse skabtes Selskabets arbejdsrytme. Personlig dyrkede han til det sidste studiet af Grundtvig. Han skulde have indledt en forhandling om emnet: »Blev Grundtvig pietist efter 1810?« på Lysebu. Ved dette stævnes åbning mindedes næstformanden Scharlings forstående og noble personlighed, der havde ønsket at bygge bro mellem modsætninger, både indenfor kirkelivet og i forholdet mellem kultur og kirke (herom vidner hans skrift »Kirken og det humane Aandsliv«, 1926). Om hans medvirken ved Selskabets stiftelse udtalte Borup, at det derved »blev løftet ud over det snævre retningspræg, det ellers kunde have fået«.

\section{Lysebu-stævnet.}

Grundtvigforsker-stævnet på Lysebu ved Oslo 27.-31. august 1951 samlede ca. 30 deltagere (maksimum for, hvad pladsforholdene på dette skønne fjeldkollegium tillod). Indbudt var Selskabets norske medlemmer, enkelte andre interesserede nordmænd ${ }^{3}$ ) og fra Danmark en række arbejdende Grundtvig-forskere, deriblandt fire studenter. Også nogle danske Lysebustipendiater deltog i møderne.

Mødets leder, den fungerende formand, Ernst J. Borup, omtalte i sin velkomst, at Grundtvig var blevet nordisk, før han blev dansk, og skildrede i hovedtræk Grundtvigs nære forhold til Norge, dets litterære udtryk og hans mange norske venskabsforbindelser. Borup overbragte en hilsen »til de nordiske doktorer i Grundtvig« fra den første udenlandske, dr. Fritz Wartenweiler ${ }^{4}$ ), der gerne vilde have deltaget i mødet.

Første dags talere var Høirup: »Grundtvig i Norge 1851« (trykt i »Vartovbogen《 1951), Ejnar Thomsen: 》Grundtvig og virkeligheden« og provst, dr. theol. Anders Skrondal, der i tilknytning til sine

$\left.{ }^{3}\right)$ De norske deltagere - udover talerne - var: Grundtvigs sønnedatter fru Marie Lorange, højskoleforstander Aslak Torjusson, højskolelærerne Norvald Dyrvik, Rune Birkeland, Jon Fanavoll og pastor Arne Frisvold. Desuden deltog dr. philos. Solveig Tunold som repræsentant for Oslo Universitetsbibliotek, universitetsstipendiaterne dr. philos. Ole Koppang og dr. philos. Hans Midbøe, samt den danske lektor ved Oslo Universitet Erling Nielsen, der forestod stævnets praktiske arrangement.

4) Disputats 1913: »Ein nordischer Volkserzieher. Die Entwicklung N. F. S. Grundtvigs zum Vater der Volkshochschule«. 
grundige afhandlinger ${ }^{5}$ ) talte om »Grundtvigs verknader i Noreg«. Næste dag talte høgskulestyrar Nils Sivertsen: »W. A. Wexels, Grundtvigs ven og vært 1851《, Albeck: »Grundtvig og Norge 1814《 og Thaning: »Kan en salme polemisere?« Denne dag gav Fondet for dansk-norsk Samarbejde festmiddag med professor Størmer som vært.

Trediedagen foretoges en udflugt til Krokkleiva i Ringerike, Norderhaugs præstegård og Sundvallen - netop de steder, Grundtvig med studentermødet gæstede i 1851. Professor, dr. philos. Francis Bull, der deltog i hele stævnet og med stedse inciterende indlæg bidrog til de mange diskussioner og samtaler, causerede på »Kongens utsikt《 over emnet »Grundtvig og Wergeland《 og fortsatte, efter frokosten på Sundvallens restaurant, med et foredrag: „Grundtvig og Bjørnson«. Aftenens foredrag på Lysebu af høgskulestyrar Albert Haugsand: »Grundtvig og den norske folkehøjskole« og en del af den efterfølgende forhandling, hvori deltog bl. a. den tilsynsførende ved de norske højskoler Ørbæk Sørheim, optoges på stålbånd og udsendtes i dansk og norsk radio ${ }^{31} / 8$ og $2 / \%$.

Grundtvig-Selskabet fik således, takket være Fondet for dansknorsk Samarbejde, den bedst tænkelige lejlighed til at styrke et dansknorsk samarbejde $i$ Grundtvig-forskningen. Det viste sig, at der fra norsk side var stor interesse for en plan, som Selskabet på forslag af Albeck flere gange har drøftet, nemlig udgivelsen af Grundtvigs omfattende brevveksling med betydelige nordmænd. Fra begge sider udtaltes ønske om et nyt norsk-dansk stævne, på Schæffergården i København 1953, men dette lod sig dog desværre ikke realisere.

Lysebustævnet fik, ligesom Ribemødet, inspirerende betydning for deltagerne, og ikke mindst glædelig var kontakten med de tilstedeværende repræsentanter for den nye generation af Grundtvigforskere. To af studenterne, Jørgen Fabricius og Knud Eyvin Bugge, har siden ydet bidrag til »Grundtvig-Studier«.

\section{Selskabets almindelige virksomhed fra efteråret 1951 til 1957.}

Årsmødet 1951 fandt på indbydelse fra biskop Øllgaard sted i Odense 18/10 i Gråbrødreklosters ærværdige sal. Som fungerende formand takkede Borup i sin beretning »Kirkeligt Samfund « for tilskud både til de studerendes rejse til Lysebu og til bibliografien over Grundtviglitteratur i »Grundtvig-Studier«. Til styrelsen valgtes (efter Scharling) Jørgen Fabricius, som derefter valgtes til sekretær, idet Toldberg på

5) Disputats 1929: »Grundtvig og Noreg«; »Kyrkje og skule 1812-72«. 
grund af andre forpligtelser ønskede at træde tilbage. Toldberg, der med iver og offervilje havde arbejdet for Selskabet, vedblev dog som leder af mødevirksomheden i København og af mikrofotograferingen. Da også pastor Morten Øllgaard, der med dygtighed og uden nogen kontorassistance havde varetaget kassererposten, på grund af sin bortflytning fra København, bad om afløsning, indvalgtes kontorchef, universitetslektor P.P. Sveistrup, i styrelsen og i forretningsudvalget som kasserer. Styrelsen konstituerede sig med den hidtidige redaktør som formand, idet Borup ikke ønskede at overtage formandsposten, og med Albeck som redaktør (dog således, at jeg endnu udgav årgang 1952, som næsten var færdigredigeret). Årsmødets talere var sognepræst Carl Weltzer, hvis foredrag »Grundtvig og Søren Kierkegaard《 i udvidet skikkelse udsendtes i Selskabets Skrifter (bind V, 1952), og professor Ejnar Thomsen, der talte om samme emne som på Lysebu.

Ved årsmødet var jeg på grund af sygdom ikke tilstede. Det nyvalgte forretningsudvalg samt den afgåede kasserer samledes første gang i Viborg Stiftsprovstegård ${ }^{21} / 1$ 1952. Et varigt resultat af dette møde blev rationaliseringen af Selskabets praktiske drift, således at det fik »fast adresse« - både for sekretariatet, kassererkontoret og den øvrige (med antallet af udgivelser stadig voksende) ekspedition - i Vartov, Farvergade 27, København K. Fru Ellen Borup varetog herefter dygtigt kontorarbejdet, indtil hun i 1955 afløtes af kontorchef L. Garsdal. Videre vedtoges det, at formanden og dr. Albeck sammen med professor Skautrup, der efter Scharlings død blev valgt til formand for tilsynet med registreringen, skulde gennemgå de udarbejdede registrant-manuskripter og fastslå principperne for registreringsarbejdet, som takket være en tredie bevilling fra Zeuthens Mindelegat kunde fortsættes.

Året 1952 begyndte med underskud som følge af Lysebustævnet og større udgifter til forrige års »Grundtvig-Studier«. Et tilskud fra Undervisningsministeriet af Statens tipsmidler hjalp på fode. Undervisningsministeriet gav også en særlig bevilling til mikrofotograferingen og Det kgl. Bibliotek viste den vilvilje at yde et tilsvarende beløb; denne ordning opnåedes også de følgende år. Ved årsmødet i Vartov ${ }^{24} / 10$ talte Uffe Hansen om 》Grundtvigs oversættelser af græske salmer« (se »Grundtvig-Studier« 1953) og Borup om »Grundtvigs skoletanker, belyst ved et par af hans digte«.

Selskabets virksomhed fortsattes de følgende år med tilskud til »Grundtvig-Studier« bl. a. fra Carlsen-Langes Legatstiftelse og Undervisningsministeriet, ligesom bevillinger fra en rakke fonds muliggjorde udsendelsen af nye bind i »Skrifter udgivet af GrundtvigSelskabet«. Som bind VII fremkom »Fra døden til livet. Grundtvigs 
tanker om liv og død« (1954), fem forelæsninger, som jeg i oktober og november 1953 holdt på Århus Universitet. Her fandt også årsmødet 1953 sted, ved imødekommenhed fra universitetets rektor, professor Skautrup. Dr. Albeck talte om »Roskilde-Riim《 og sognepræst Svend Zachariassen holdt lysbilledforedrag om »Grundtvigs indflydelse på dansk kunst《 (se »Vartovbogen« 1954).

Året 1954 blev det hidtil mest begivenhedsrige i Selskabets korte historie. For det første opnåedes en bevilling af uvant størrelsesorden til registreringen (se nærmere s. $21 \mathrm{f}$. her). For det andet kulminerede udgivervirksomheden, idet Selskabet udover årbogen kunde befordre tre bind 》Skrifter《 (VI-VIII) i trykken. Tillige opnåede medlemmerne favørpris på tre bøger, udgivet andetsteds. I årets løb holdtes fire møder i København (se noten s. 15), foruden årsmødet ${ }^{22} / 10$, hvis talere var W. Michelsen: »Grundtvig som kulturpsykolog« (se »Grundtvig-Studier« 1955) og P. Skautrup: »Sproget i Grundtvigs salmer«.

I anledning af 150-året for Grundtvigs fremtræden som skribent afholdt Det kgl. Bibliotek og Grundtvig-Selskabet i fællesskab en udstilling i Bibliotekets forhal. Ved åbningen 7/5 1954 takkede formanden rigsbibliotekar $P$. Birkelund og bibliotekets embedsmænd for den forståelse og hjælpsomhed, som Biblioteket havde vist Grundtvigforskningen ikke blot ved denne lejlighed men gennem årene. Fra Bibliotekets side havde bibliotekarerne Erik Dal og Tue Gad og fra Selskabets Toldberg og Steen Johansen medvirket ved tilrettelæggelsen af udstillingen, som fik stort besøg, og hvis katalog: »Grundtvig, hans liv og gerning giver et fyldigt indtryk af det udstillede materiale. Grundtvigs efterkommere, som havde stillet en del af dennes ejendele til rådighed, var særligt indbudt til åbningen, hvor professor Francis Bull talte om Grundtvig og Bjørnson. Bagefter var rigsbibliotekaren og de indbudte Selskabets gæster i Vartov, hvor GrundtvigBiblioteket forevistes.

Få dage senere, den 15. maj, hundrede-årsdagen for Frederik Lange Grundtvigs fødsel, nedlagde Selskabets formand og næstformand en krans på dennes grav på Vestre Kirkegård, og en mindesammenkomst holdtes i Vartov, hvor fru Marie Lorange, Oslo, F. L. Grundtvigs eneste datter og - som udsending fra det af ham ledede »Dansk Folkesamfund i Amerika《 - Julius M. Nielsen, Solvang, Californien, var kommet til stede. Sidstnævnte har senere virket for udbredelsen af Selskabets skrifter i dansk-amerikanske kredse.

Grundtvig-Selskabet kom 1/3 1955 første gang »på finansloven« (konto § $21 \mathrm{XV}$ D. 6a. Tidsskrifter og Selskaber). Blandt de skrifter - udover Selskabets egne -, som i årets løb blev tilbudt medlemmer 
til forudbestillingspris, var Gustav Albeck: »Omkring Grundtvigs Digtsamlinger«, Ernst J. Borup og fotograferne Holt \& Madsen: »Minderige Steder i Grundtvigs Liv« samt Høirup og M. F. Blichfeld: »Frederik Lange Grundtvig« (under medvirkning af dr. I. M. Boberg og Hans Eriksen). Ved udsendelsen af sidstnæunte bog $8 / 11$ 1955 talte formanden og pastor Blichfeld ved et møde i Vartov om F. L. Grundtvig.

Årsmødet 1955 holdtes for anden gang i Odense 8/9 og var tilrettelagt i forbindelse med det »Kirkelige Efterårsmøde«, som hvert år holdes på Grundtvigs fødselsdag. Første foredrag, om »Det levende ord«, holdtes af Høirup, og det andet, om »Christenhedens Syvstjerne«, af Balslev. Ved styrelsesmødet besluttedes det at oprette en fond til minde om Magnus Stevns med det formål at fremme studiet af Grundtvigs salmedigtning ved at bekoste forelæsninger og udgive afhandlinger herom. Fondens styrelse vælges af Grundtvig-Selskabets styrelse og består foreløbig af fru læge Johanne B. Stevns, pastor Th. Balslev og formanden. Meddelelse til medlemmerne om Magnus Stevns' Mindefond udgik i april 1956, anbefalet af rektor G. J. Arvin, provst mag. art. Vagn Riisager og forfatteren Erik Rostbøll. Fondens kapital, som stadig står åben for indbetaling af bidrag (på GrundtvigSelskabets giro nr. 575 98), tillader endnu ikke at begynde virksomheden.

I 1956 udsendte Selskabet en ny brochure med oplysninger om dets formål og organisation samt en fortegnelse over alle dets publikationer. Denne »folder《 kan fås ved henvendelse til Selskabets kontor. I årets løb udkom bind IX og X af »Skrifter《, W. Michelsen: »Den sælsomme forvandling i N. F. S. Grundtvigs liv« og N. F. S. Grundtvig: »Taler på Marielyst Højskole 1856-1871« (ved Steen Johansen). Det sidstnæunte skrift fremkom $\mathrm{i}$ anledning af hundredeåret for indvielsen af Grundtvigs egen højskole 3/11 1856.

Ved årsmødet ${ }^{18 / 10} 1956 \mathrm{i}$ Vartov indvalgtes professor P. G. Lindhardt, universitetslektor, cand. mag. Niels Kofoed og pastor Valdemar Nielsen i styrelsen, og den sidstnæunte afløste pastor Fabricius som Selskabets sekretær. Albeck talte om »Grundtvig og universiteterne«, og ved aftenmødet, hvortil Københavns Højskoleforening var indbudt, holdt Borup foredrag om »Grundtvigs Højskole på Marielyst«. 


\section{Registreringen af Grundtvig-Arkivet.}

I 1953 kunde den allerede (side 13f. og 18) omtalte foreløbige registrering af en del af Grundtvig-arkivet bringes til afslutning. Tilsynet, der efter Ernst Frandsens død ${ }^{28} / 21952$ bestod af Skautrup, Høirup og Albeck, gennemgik de fem afleverede registrant-manuskripter, hvori en meget betydelig arbejdsindsats var nedlagt. Der var undersøgt og beskrevet 139 fascikler samt nogle papirer i privat eje. Tilsynet afgav en beretning (dateret Århus ${ }^{23} / 2$ 1953), som dels indeholder en oversigt over det udførte arbejde, dels opstiller en række retningslinier for fremgangsmåden ved fortsættelsen deraf (manuskriptbeskrivelse, udarbejdelse af regest, angivelse af dateringskriterier $\mathrm{m} . \mathrm{m}$.), der siden blev normgivende for den endelige registrering, som tiden nu, efter de indvundne erfaringer, var moden til at søge fremmet.

Efter aftale med Skautrup, der var forhindret, indbød formanden alle de registrerende til et møde i Grundtvig-Biblioteket i Vartov $7 / \%$ 1953. Her udarbejdedes en plan over fordelingen af arkivet mellem deltagerne samt en beregning af det timetal, disse kunde påtage sig indenfor en 2-årig periode. Det vedtoges, at Albeck på grundlag af Århus-beretningen skulde udarbejde et standardblad til brug ved registreringen og Steen Johansen en forkortelsesliste.

Ved en forhandling den følgende dag med Det Danske Sprogog Litteraturselskab gav dettes formand, overbibliotekar, dr. phil. $H$. Topsøe-Jensen og administrator, dr. phil. Albert Fabritius, tilsagn om at ville anbefale styrelsen for Litteraturselskabet at støtte GrundtvigSelskabets registreringsplan. Dr. Topsøe-Jensen udtalte, at det måtte anses for både meget påkrævet og meget værdifuldt at undersøgelsen af Grundtvigs papirer gennemførtes efter Århus-beretningens principper og med den prøvede medarbejderstab. Det aftaltes, at tilsynet skulde føres af professor Skautrup på Litteraturselskabets vegne og af stiftsprovst Høirup på Grundtvig-Selskabets, henholdsvis for de humanistiske og de teologiske manuskripters vedkommende, og Litteraturselskabet vilde stille sit administrative apparat til rådighed.

En fælles ansøgning fra de to selskaber blev indgivet til Statens almindelige Videnskabfond, som ${ }^{1 / 4} 1954$ bevilgede $54.000 \mathrm{kr}$. til arbejdet. Gennem de følgende to år blev nu omkring halvdelen af Grundtvigs papirer registreret. Registratorer var: Gustav Albeck, Uffe Hansen, Steen Johansen, William Michelsen, Kaj Thaning, Helge Toldberg, K. E. Bugge og Niels Kofoed. De to sidstnæunte havde også deltaget under sidste del af den foreløbige registrering.

Arbejdet med registreringen af Grundtvig-arkivet - det største 
danske privatarkiv fra det 19. århundrede - er den mest omfattende og foreløbig vigtigste af de opgaver, som Selskabet har taget op. Den systematiske og indgående gennemgang af dette valdige materiale er den uomgængelige forudsætning for det fremtidige studium af Grundtvigs liv og forfatterskab. I forståelse af registreringens grundlæggende betydning for studiet af Grundtvig - og dermed af forrige århundredes litteratur-, kultur- og kirkehistorie - stillede Det Danske Sprog- og Litteraturselskab sig - med sin store erfaring og dygtige administration - ved Grundtvig-Selskabets side i løsningen af opgaven, og samarbejdet er i enhver henseende forløbet godt. Det må også påskønnes, at først Zeuthens Legatstiftelse og siden Videnskabsfonden kunde yde de fornødne bevillinger på et tidspunkt, hvor det var muligt at sikre medarbejdere med de nødvendige, ganske særlige kvalifikationer.

Pr. ${ }^{1 / 12} 1955$ var der af arkivets ialt 535 fascikler registreret 241, og ved udløbet af den to-årige bevilling fra Statens almindelige Videnskabsfond var, som beregnet, halvdelen af materialet behandlet. Ved en ny, eet-årig bevilling 1/4 1956 på 16.000 kr. muliggjorde Fonden arbejdets fortsættelse, og først på året 1957 kunde de to selskaber offentliggøre de forste tre bind af »Registrant over N. F. S. Grundtvigs Papirer $\ll$, omfattende fasc. 1-128. Registranten fremstilles i 50 eksemplarer, og de fleste aftages af hovedbibliotekerne i Norden og det vestlige udland. Grundtvig-Selskabets medlemmer fik i april 1957 tilbudt registranten til køb for en efter fremstillingsomkostningerne meget billig pris. Udgivelsen af dette $\mathrm{i}$ sin art enestående værk vil formentlig strække sig over ca. fem år, og man regner, at der vil komme omkring 25 bind, hvert på 250-300 blade. Vi skylder Litteraturselskabet stor tak for dets medvirken til at resultatet af så mange års og så mange forskeres arbejde således gøres offentlig tilgængeligt.

\section{Arbejdsopgaver hjemme og ude.}

Grundtvig-Selskabet af 8. September 1947 har til formål at udbrede kendskabet til N. F. S. Grundtvig og at fremme studiet af hans virke og hans stilling $\mathrm{i}$ åndslivet $\mathrm{i}$ og udenfor Danmark. Selskabet ønsker at skabe en levende kontakt mellem alle, der virker udfra Grundtvigs tanker og arbejder med hans åndelige indsats.

Ved udgangen af Selskabets første tiår har styrelsen fundet det rigtigt at give en samlet oversigt over det arbejde, som er udført. De beretninger, som har været aflagt ved årsmøderne, har aldrig været trykt (vi mente at burde forbeholde den kostbare plads i årbogen til 
forskningsopgaver) og dette har medført, at denne redegørelse måtte blive ret omfattende og detailleret.

Den første betingelse for, at Grundtvig-Selskabet kunde virke for sit formål, var, at det kunde vinde - og bevare - tilstrækkelig mange medlemmer, som sluttede op om arbejdet. Med glæde kan vi erkende, at dette har været tilfældet. Den anden forudsætning var, at den videnskabelige forskning af Grundtvig blev drevet i et omfang og var af en kvalitet, som berettigede Selskabets eksistens. Her må Selskabet vedkende sig sin store taknemlighedsgæld til den lange række af forskere, der - oftest uden honorar - har fremlagt deres undersøgelser i foredrag, i afhandlinger til årbøgerne eller i »Skrifter udgivet af Grundtvig-Selskabet«. Alle disse udgivelser - og især den sidstnævnte række - har kun været mulige ved opnåelse af mange tilskud fra bevilgende myndigheder og legatstiftelser, som har vist meget stor forståelse for Selskabets publikationsvirksomhed.

Selskabets mødevirksomhed har væsentlig indskrænket sig til årsmøderne og de nævnte enkelte foredrag. Til afholdelse af flerdages forskermøder - i lighed med Lysebu-stævnet - helst med deltagelse af de stedse flere udenlandske Grundtvigforskere, har Selskabet desværre hidtil savnet midler.

I de kommende år vil der - udover afslutningen af registreringen - melde sig talrige arbejdsopgaver for Grundtvig-Selskabet. Jævnsides med de fortsatte litteraturhistoriske undersøgelser vil en videreførelse af studiet af Grundtvigs kirkelige skrifter - ikke mindst prædikenerne - være ønskelig, og et samarbejde mellem litteraturhistorikere og teologer vil kunne bære frugter på den uudtømmelige arbejdsmark, som salmerne frembyder. Endelig må der arbejdes på at fremskaffe ny og bedre udgaver af længst udsolgte, centrale værker af Grundtvig, og spørgsmålet om udgivelse af utrykte arbejder vil stadig rejse sig.

Grundtvigs opdragelsestanker trænger også til fornyet behandling og drøftelse. På dette felt er muligheden for at bringe Grundtvigs synspunkter frem i udlandet i særlig grad tilstede. I alle demokratiske lande er virkeliggørelsen af »adult education « $i$ dag et hovedproblem og en fremlæggelse af højskoleskrifterne på hovedsprogene vil derfor være en naturlig opgave. Der spores i de senere år tillige en stigende interesse for Grundtvigs kirkesyn, især i De forenede Stater, hvor overbibliotekar, dr. J. Chr. Bay har gjort en værdifuld indsats for Grundtvig-Selskabet. To disputatser om Grundtvig er fremkommet, af Glenn Martin og Ernest D. Nielsen. Grundtvig-Selskabet har givet sin anbefaling til udgivelsen af den sidste (»N. F. S. Grundtvig. An American Study«, 1955) og ligeledes til udgivelsen af professor, dr. 
Johannes Knudsens bog: »Danish Rebel. The Life af N. F. S. Grundtvig« (1955).

Forholdet til Norge - det land, hvor Selskabet har de rigeste historiske tilknytningspunkter - har tidligere været omtalt. Hinsides Sundet blev 8/11 1954 i Gamleby det svenske Grundtvig-Selskab stiftet, bestående af præster og lægmænd, især på østkysten, med teol. d:r., kyrkoherde Julius Welhagen som formand. Selskabet har folkeligtkirkeligt sigte, i lighed med »Kirkeligt Samfund« herhjemme. Det svenske Selskab arbejdede i 1955 særligt med Grundtvigs skoletanker, og 21.-22. juni besøgte ca. 35 af dets medlemmer Vartov, hvor de modtoges af forstander Borup ${ }^{8}$ ).

I denne forbindelse kan nævnes, at man ved årsmødet i 1954, hvortil der indløb en hilsen fra biskop Karl Marthinussen, Stavanger, drøftede muligheden for udvidet kontakt med de lande, hvor Grundtvig-Selskabet har medlemmer. Til enkelte institutioner i Norge, Finland og Tyskland har Selskabet sendt sine publikationer, men vi savner midler til en sådan udbredelse i det ønskelige omfang.

Øverst på Selskabets ønskeseddel i henseende til at udbrede kendskabet til Grundtvig i udlandet står i øjeblikket den side 17 her nævnte plan om en samlet udgivelse af Grundtvigs korrespondance med nordmænd - et brevstof af usædvanlig kulturhistorisk interesse - og tanken om at tilvejebringe gode oversættelser til tysk og engelsk af hovedværker af Grundtvig. Den af J. Tiedje besørgede tyske Grundtvig-udgave (Eugen Diederichs Verlag, Jena 1927) er for længst udsolgt og er - tiltrods for sin fortjeneste som pionérarbejde - uegnet til genudgivelse. I 1949 fik Selskabet oplyst, at et andet tysk forlag vilde påtage sig en udgave i 2 bind, såfremt redaktion og oversættelse kunde betales fra dansk side. På daværende tidspunkt, hvor Selskabet »kæmpede for livet« og hjemsøgte alle tænkelige offentlige midler for at få sine første publikationer udgivet og registreringen begyndt, var det ikke muligt at binde an med denne påkrævede opgave. Fra amerikansk side blev der i 1950 overfor Selskabets sekretær udtalt ønske om udgivelse af et engelsk udvalg af Grundtvigs skrifter, men heller ikke denne plan har det endnu været gørligt at tage op til løsning, skønt den - efter det opsving, som Grundtvig-forskningen i engelsksprogede lande i den senere tid har taget - er så nærliggende.

Der foreligger således mangfoldige og omfattende opgaver hjemme og ude, som det vil være rimeligt at gå i gang med i den fremtid, som Grundtvig-Selskabet håber at få for sin virksomhed.

6) Grundtvigssälskapets första år (Västerviks-Tidningen 10/11 1955). 